\author{
https://doi.org/10.52449/1857-4114.2020.36-2.11
}

CZU: 796.8.81:612.6

\title{
AGE ASPECT OF THE JUDOKA SPORTSMANSHIP TRAINING
}

\author{
Manolachi Victor ${ }^{1}$, ORCID: 0000-0002-3904-3564 \\ ${ }^{1}$ State University of Physical Education and Sport, Chisinau, Republic of Moldova
}

\begin{abstract}
This article presents an analysis of the well-known specialized literature on the issue of proper coverage of the problems of competitive development and range of competitive success in different age periods of the training process of athletes in judo wrestlers, as fundamental in the qualitative mastering of the motor-technical potential for the achievement of higher sportsmanship. This analysis compares the substantive aspects of this issue in various sources and assesses their significance for the training process.
\end{abstract}

Keywords: sports wrestling; specialization; general didactic principles; training process; types of wrestling; sports improvement; current stage; literary sources; contemporary authors; methods and means; physical training; structure of the training process; power qualities; judo wrestling.

Introduction. The systematic process of training sportsmanship in wrestling from the beginning of sports activities to reaching higher achievements should be based on the basic principles of general didactics adapted to specific sports and several particular tenets. It is the reliance on these principles arising from objective laws of the theory and methodology of sports training, some related disciplines (anatomy, physiology, biochemistry, biomechanics, sports medicine, genetics, psychology, etc.), as well as some general scientific theories and approaches (a systematic approach, adaptation theory, theory of functional systems, theory of movement control, etc.), determines the effectiveness of the process of long-term improvement of athletes concerning the process of training sportsmanship in general, and to individual aspects of preparation (technical, physical, psychological, tactical) or personal motor qualities, in this case, power.

The realization of the potential of both general didactic and particular principles should be reflected in the general structure of the process of long-term improvement and its content about all long-term dynamics reflected in the training programs for each year or stage. Here, about strength training, a unique role is assigned to the principle of compliance of the process of force training with the characteristics of age development, puberty, the features of the male and female body, and the direction of submission of the content of strength training with the main focus and the tasks of various structural formations of the training process in the system of long-term and annual training $[6,8]$. To implement these principles, clear ideas are needed about the main characteristics of the ascent of athletes to the heights of sportsmanship. The development of strength qualities in the long-term improvement of athletes specializing in wrestling and other sports is conditioned by many factors. These include the general structure of the process of long-term training, the predominant focus and content of each of its stages, age and gender characteristics of athletes, the peculiarities of the puberty period, sensitive periods about various types of strength qualities, the connection between strength training and the structure of competitive activity, etc. $[4,7,10,11,12]$. 
It is no less important to understand that there are many morphological and physiological components in the structure of strength preparation, which together provide the level of various types of strength qualities. And each of these components related to the construction of muscle tissue, neuroregulatory processes of motor units activation of muscles, the energy supply of muscle activity, biomechanical system of movements, etc. cannot be subjected to highly effective development without taking into account the age and gender characteristics of the trainees, the specificity of the sport, the stage of longterm improvement, and the period of annual training [1, 2, 5, 10, 13].

It is imperative to approach the strength training of athletes not as an isolated process focused on achieving the maximum available strength capabilities, but as a process, the result of which should be an integral part of versatile preparation, combining various types of strength qualities with speed and coordination abilities, mobility in joints and endurance, technical and tactical characteristics, that is, into a system that determines the effectiveness of competitive activity in all its complexity and multifactorial nature [2, 9]. It is pretty natural that this context in the strength training of athletes also provides for its close relationship with the age and gender of the athlete, the stage of longterm and annual training, sports specialization, and the model of competitive activity $[2,3]$.

By now, about each of the numerous factors related to athletes' strength training, a vast amount of empirical and theoretical knowledge has been accumulated, which allows revealing the tasks, means, and methods of strength training about each of the stages of long-term improvement. However, this can be done only if there is a general structure of long-term training, which includes such indicators as the optimal age for starting wrestling, the duration of preparation for the first sporting successes and the generation of athletes who achieve them, the time of the period from the first successes to the highest achievements and the age at which they were available. This knowledge is the basis on which, relying on abundant empirical and theoretical material, one can structure the entire structure of long-term training and show the place, directivity, means, methods of strength training in their dynamics with the task of bringing an athlete to the highest level of particular strength preparation in optimal this age zone.

Organization and research methods. According to scientific publications experts in sports, the study of the issue on the presented topic was carried out. It was compared with the practice of the training process in different age groups of judo wrestlers. As a result, we have obtained and summarized the data of 34 highly qualified athletes who became winners and prize-winners of the 1996-2016 Olympics.

Athletes who have achieved success in the Olympic arena began to train at different ages from 3-5 to 11-12 years-old. However, the overwhelming majority of athletes started training at the age of 7-11 years-old.

Research results. The beginning of training in this kind of wrestling is not connected with the peculiarities of national judo schools. For example, at an early age (3-5 years-old), began to practice judo athletes from Kazakhstan (Yeldos Smetov), Japan (Ryunosuke Haga, Keiji Suzuki), France (Teddy Riner), Italy (Giuseppe Maddaloni) and others. At the age of 11-12 years-old began their sports career Rishod Sobirov (Uzbekistan), Tagir Khaybulaev și Dmitri Nossov (Russia), Dimitri Peters (Germany), Nuno Delgado (Portugal), Toshihiko Koga (Japan), David Douillet (France).

The average age of the beginning of training for outstanding athletes was a little more than 8 years-old, which is slightly lower than that of the Greco-Roman and freestyle wrestlers who started training at the age of 10 . On the other hand, the spread at the beginning of judo lessons (9 years) corresponds to that which is typical for Greco-Roman and freestyle wrestling. On average, judokas achieve their 
first sporting successes at the age of 21 , with fluctuations, in the overwhelming majority of cases, from 18 to 22 years. Only in some instances athletes achieved a sufficiently high level of skill at the age of 24 (Tagir Khaybulaev, Dmitri Nossov - Russia; Hisayoshi Kharasawa - Japan) and even 26 years old (Anatoly Laryukov - Belarus). Thus, the age range for achieving the first sport's success is significantly narrower (almost 4 years) than the spread characteristic of the age at which sports activities begin.

Interestingly, the length of the path from the start of sports to the first successes is not related to the age at which the athletes began to exercise. For example, the Italian Giuseppe Maddaloni, who started to practice judo at the age of 3, achieved his first success at 21, i.e., 18 years since training. The Japanese Keiji Suzuki has covered this path in 19 years-old (from 3 to 22 years-old). Other athletes have achieved a high level of sportsmanship in a much shorter period - 8-10 years (Toshihiko Koga (Japan), Nunu Delgado (Portugal), Rishod Sobirov (Uzbekistan).

The level of the highest achievements, judo athletes, on average, reach at the age of 22 . More than $80 \%$ of athletes included in the research program achieved the highest accomplishments at the age of 21-23, which allows us to consider this age zone optimal for demonstrating high sportsmanship.

Athletes specializing in judo, on average, achieve the highest results in a sports career at the age of 25 , i.e. in the same way as GrecoRoman and freestyle wrestlers. Most athletes achieve outstanding results between the ages of 23-25. However, quite often, the highest achievements are obeyed by older athletes Anatoly Laryukov (Belarus) - 29 years old, Travis Stevens (USA) - 30 years old, Alexander Mehaylin (Russia) and Movlud Miraliev (Azerbaijan) - 33 years old.

From the first sporting successes to achieving the highest results, it took athletes 4 years on average. However, for some of them, this path turned out to be shorter - no more than 3 years-old (Arsen Galstyan, Mansur Isaev, Ivan Nikiforov - Russia; Keiji Suzuki - Japan; Jung Bu-Kyung - South Corea; Giuseppe Maddaloni - Italy), and for others, it lasted for 8-13 years-old (Udo Quellmalz - Germany; Movlud Miraliev - Azerbaijan; Alexander Mihaylin - Russia; Travis Stevens - USA).

An analysis of the sports careers of all champions and prize-winners of the 2012 and 2016 Olympics leads to similar results.

Athletes who achieved success at the 2012 London Olympics achieved their first sporting success at an average age of 21 . They reached the highest achievements after a year of training, and the highest results achieved, on average, four years later, at the age of 26. An analysis of the results of the 2016 Olympics in Rio de Janeiro leads to approximately the same results: the first sporting successes - at the age of 20, reaching the level of the highest achievements - 22 years-old, the achievement of the highest development - 25 years-old.

The sports career of outstanding athletes is usually not limited to achieving the highest results. Most of them continue active training and competitive activities. Athletes who specialize in judo end their sports careers at an average age of 28, i.e. three years after achieving the highest results. However, some judokas give up their sports careers immediately after achieving success at the Olympics. This happened, for example, with the sports fate of the Italian athlete Fabio Basile, who won the 2016 Olympics in the weight category up to $66 \mathrm{~kg}$. This is mainly due to the unexpected success of this athlete, who by the time of the Olympic tournament did not differ in exceptional achievements and occupied only the 29th position in the world ranking of judokas in this weight category.

Immediately after his success at the 2016 Olympics (silver medal), 30 years-old American athlete Travis Stevens (category up to $81 \mathrm{~kg}$ ) completed his sports career. However, unlike Fabio Basile, he successfully performed on the world stage for more than 10 years, twice becoming the champion of the Pan 
American Games (2007 and 2015), performing in many other prestigious competitions.

The successful performance of overweight athletes at the Olympics, as a rule, leads to their retirement from the great sport, which is quite natural and easy to explain. Thus, for example 33 years-old Movlud Miraliev (Azerbaijan), who managed to win a bronze medal at the 2016 Olympics, winner of the 2012 Olympics in the under $100 \mathrm{~kg}$ category 28-year-old Russian Tagir Khaibulaev, winner of the 1996 Olympics in the under 65 category $\mathrm{kg} 29$ years-old sportsman from Germany Udo Quellmalz.

The younger winners and medalists of the Games of the Olympics, as a rule, seek to extend their sports careers. Thus, for example, the Japanese judoka Keiji Suzuki, who became the Olympic champion in the over $100 \mathrm{~kg}$ category in 2004 when he was 24 years-old, continued his sports career for another 8 years-old, becoming the world champion twice and leaving the sport at the age of 32 after winning a bronze medal at the world championship.

The winner of the Sydney Olympic Games in 2000 in the category up to $73 \mathrm{~kg}$, 24-year-old Italian Giuseppe Maddaloni, played on the world stage for another 8 years, ending his sports career with a bronze medal at the European Championships. However, older athletes who have achieved success at the Olympic Games often continue to train and compete actively. For example, an athlete from Belarus Anatoly Laryukov, after winning a bronze medal at the 2000 Olympics, when he was 30 years-old, successfully performed on the world stage for another four years, winning the European Championship (2002), becoming a prize-winner of some other major competitions.

Alexander Mihaylin (Russia), who performed in the category over $100 \mathrm{~kg}$, achieved his most tremendous success in 2012, becoming the world champion and silver medalist of the Olympics. This success was preceded by a successful 13 year career, during which he won the World Championships three times and the European Championships six times. However, after the success of 2012, the 33 years-old athlete did not end his career but continued it until the age of 37 , having won the 10th Russian title in his career in 2016.

Conclusions. Thus, in judo, two stages of a sports career are visible. The first covers the time interval from the beginning of sports activities to reaching higher achievements - 11 years-old - from 10 to 22 years-old. After that, the second stage of a long-term sports career begins, with an average duration of 6 years-old (up to 28 years-old of age) with an extensive range of individual fluctuations. Moreover, for some athletes (for example, Fabio Basile), this stage may not occur due to the end of a career after achieving the highest result. On the other hand, it can drag on for 10 or more years for other athletes, and some of them (for example, Alexander Mihaylin) - for 18 years-old.

\section{References:}

1. Бар-Ор О., Роуланд Т., Андреев И. (2009). Здоровье детей и двигательная активность: от физиологических основ до практического применения. [пер. с англ.]. Киев: Олимпийская литература. 528 с.

2. Булатова М.М., Бубка С.Н., Платонов В.М. (2019). Олімпійський спорт у системі гуманітарної освіти: навчальне видання. Киів: Перша друкарня. 912 с.

3. Вайцеховский С.M. (1985). Система спортивной подготовки пловцов $к$ Олимпийским играм. [Диссертация] Д-р. пед. наук. Москва. 368 с. 
4. Гужаловский А.А. (1984). Проблема критических периодов онтогенеза в ее значении для теории и практики физического воспитания. В кн.: Очерки по теории физической культуры, 1-е изд. Москва: Физкультура и спорт, с. 211-224.

5. Коц Я.М. (1986). Спортивная физиология. В кн.: Спортивная физиология, 1-е изд. Москва: Физкультура и спорт, с. 145-65.

6. Манолаки В.В. (2019). Общедидактические и специальные принципы в системе силовой подготовки борцов различного стиля. В: IX Международной научной конференции студентов и молодых ученых «Университетский спорт: здоровье и процветание нации» посвященной 75-летию Казахской академии спорта и туризма. Алматы, Казахстан, с. 197 200.

7. Набатникова М.Я., Филин В.П. (1995). Построение процесса спортивной подготовки. В кн.: Современная система спортивной подготовки. Москва: СААМ, с. 351-389.

8. Платонов В.Н. (2017). Двигательные качества и физическая подготовка спортсменов. Киев: Олимпийская литература. 657 с.

9. Платонов В.Н. (2015). Система подготовки спортсменов в олимпийском спорте. Общая теория и ее практические приложения: учебник [для тренеров]: в 2 кн. Киев: Олимпийская литература, Кн. 2. 752 с.

10. Филин В.П., Фомин Н.А. (1980). Основы юношеского спорта. Москва: Физкультура и спорт. 255 с.

11. Bompa T.O., Haff G.G. Periodization: Theory and Methodology of Training. 5th ed. Champaign, IL: Human Kinetics.

12. Kraemer W., Fry A., Frykman P. (1989). Resistance training and youth. In: Pediatric Exercise Science, no 1, p.336-350. $490 \mathrm{p}$.

13. Robergs R.A., Roberts S.O. (2002). Fisiologia do Exercicio. Sao Paulo: Phorte Editora. 